Ann. Biol. anim. Bioch. Biophys., 1979, 19 (3 B), 769-773.

\title{
Effect of vitamin $D$ or calcium deficiency on duodenal, jejunal and ileal calcium-binding protein and on plasma calcium and 25-hydroxycholecalciferol levels in the growing pig
}

par Monique THOMASSET, A. POINTILLART *, Paulette CUISINIER-GLEIZES, L. GUÉGUEN *

with the technical assistance of N. GOUHIER, A. SUBRENAT, C. COLIN and A. PORTEU

INSERM U. 120 (Pr H. Mathieu), 44, chemin de Ronde, 78110 Le Vésinet

* Station de Recherches de Nutrition I.N.R.A. 78350 jouy en Josas.

Summary. In vitamin D-deficient pigs the amount of intestinal calcium-binding protein (CaBP) decreased by 33 p. 100 in the proximal duodenum and by 70 p. 100 in the midjejunum ; it was unmeasurable in the distal ileum. Plasma calcium levels declined significantly and plasma 25-hydroxycholecalciferol level was undetectable. The pigs adapted to a calcium-deficient diet by considerably increasing jejunal and ileal CaBP.

In chicks and rats, 25-hydroxycholecalciferol $\left(25-\mathrm{OHD}_{3}\right)$ is the major circulating metabolite of vitamin $D_{3}$, whereas 1,25 -dihydroxycholecalciferol $\left(1,25(\mathrm{OH})_{2} \mathrm{D}_{3}\right)$ is the major hormonally active metabolite of vitamin $D_{3}$ increasing intestinal absorption of calcium and inducing the synthesis of intestinal calcium-binding protein (CaBP) (Spencer ef al., 1976). In these species evidence is now accumulating that CaBP is probably involved in the complex process of intestinal calcium transport (Wasserman, Taylor and Fullmer, 1974). On the other hand, little is known concerning vitamin D metabolism and its action mechanism in pigs. The present study reports the effect of vitamin $\mathrm{D}$ or calcium deficiency on $\mathrm{CaBP}$ isolated from the proximal duodenum, midjejunum and distal ileum, and on plasma calcium and $25-\mathrm{OHD}_{3}$ levels.

\section{Material and methods.}

\section{- Animals and Diets.}

Vitamin-D deficiency. - Two groups of Large-White pigs were used. In the first group, vitamin D-deficient pigs were produced as previously described (Pointillart, Garel and Guéguen, 1978). From weaning at 5 weeks of age, the piglets received a semi-synthetic vitamin D-deficient diet containing 0.9 p. $100 \mathrm{Ca}$ and $0.6 \mathrm{p} .100 \mathrm{P}$. In the second group, control pigs were produced from sows receiving the standard pig diet 
with the usual vitamin $D$ content. After weaning at 5 weeks, they received a semisynthetic diet containing 0.8 p. $100 \mathrm{Ca}, 0.6 \mathrm{p} .100 \mathrm{P}$ and $2500 \mathrm{IU}$ of vitamin $\mathrm{D}_{3} / \mathrm{kg}$ of diet. The animals were slaughtered 7 to 8 weeks later. 13 pigs of each group were used.

Calcium deficiency. - Five-week old $L$. W. piglets received either a low-calcium $\operatorname{diet}(0 \mathrm{Ca})(0.1$ p. $100 \mathrm{Ca}, 0.6$ p. $100 \mathrm{P})$ or a control diet $(\mathrm{NCa})(0.8 \mathrm{p} .100 \mathrm{Ca}, 0.6 \mathrm{p} .100$ P) containing $2500 \mathrm{IU}$ of vitamin $D_{3} / \mathrm{kg}$ diet. Seven pigs in each group were slaughtered 4 weeks later.

- Calcium-binding protein (CaBP) analysis (Freund and Bronner, 1975). $20 \mathrm{~cm}$ of the proximal duodenum, mid-jejunum and distal ileum of each animal were excised, everted and the mucosal tissue homogenized in $4 \times$ its volume of a modified Trissaline buffer ; the homogenate was centrifuged at $100000 \mathrm{~g}$ and the supernatant lyophilized ( $(100)$. A low molecular weight fraction was isolated from this material by Sephadex G-75 column chromatography (dimensions : $1.6 \times 100 \mathrm{~cm}$ ). This material (peak B, $v_{e} / v_{0}=2.0$ ) was pooled and defined as $\mathrm{CaBP}$. The CaBP content was evaluated by its calcium-binding activity determined as a function of the assay calcium concentration ; the amount of added calcium was $0-100 \mu \mathrm{g} / \mathrm{ml}$ and the final free calcium concentration varied from 0.2 to $15 \mu \mathrm{M}$. The binding data were analyzed by saturation kinetics. The calcium-binding capacity was calculated by the method of Scatchard and expressed as $\mathrm{nmol} \mathrm{Ca}$ bound/mg protein in peak B. Equal amounts $(175 \mathrm{mg})$ of S100 protein were applied to the column for quantitative comparison. All procedures were carried out at $4^{\circ} \mathrm{C}$. Protein was monitored at $280 \mathrm{~nm} .{ }^{45} \mathrm{Ca}$ was analyzed by liquid scintillation.

- Plasma analysis. "Vitamin D status " was evaluated by the plasma concentration of $25-\mathrm{OHD}_{3}$ measured by a competitive protein-binding assay (Belsey, De Luca and Potts, 1974). Plasma calcium was determined by atomic absorption spectrophotometry.

TABLE 1

Effect of vitamin D-deficient dief on duodenal, jejunal and ileal CaBP contents and plasma $\mathrm{Ca}$ and $25-\mathrm{OHD}_{3}$ levels

\begin{tabular}{|c|c|c|c|c|c|}
\hline \multirow[b]{2}{*}{ Pigs } & \multicolumn{2}{|c|}{ Plasma } & \multicolumn{3}{|c|}{ Intestine } \\
\hline & $\underset{\mathrm{mg} / \mathrm{la}}{\mathrm{Ca}}$ & $\underset{\mu \mathrm{g} / \mathrm{I}}{25-\mathrm{ODD}_{3}}$ & $\begin{array}{l}\text { Duodenum } \\
\text { CaBP }\end{array}$ & $\begin{array}{l}\text { Jejunum } \\
\text { ol } \mathrm{Ca} \text { bound } / \mathrm{n}\end{array}$ & $\begin{array}{l}\text { lleum } \\
\text { rotein) }\end{array}$ \\
\hline $\begin{array}{c}\text { vit } D_{3} \\
(13)\end{array}$ & $102 \pm 1.2$ & $22 \pm 2.1$ & $82 \pm 8.2$ & $14 \pm 4.0\left(^{a}\right)$ & $0.6 \pm 0.66$ \\
\hline $\begin{array}{l}0 \text { vit } D_{3} \\
(13)\end{array}$ & $90 \pm 3.6$ & $<4\left(^{b}\right)$ & $55 \pm 7.5$ & $4 \pm 2.3\left({ }^{a}\right)$ & $0.0 \pm 0.00$ \\
\hline $\mathbf{p}$ & $<0.02$ & $<0.001$ & $<0.002$ & $<0.01$ & NS \\
\hline
\end{tabular}

The values in parentheses represent the number of pigs. The results are the means \pm SEM. Statistical significance was analyzed using Student's t-test : p represents the significance between vitamin D-supplemented and vitamin D-deficient pigs. NS : not significant.

(a) Significantly different from the other segments $p<0.001$.

(b) The values are lower than assay sensitivity or not significantly different from 0 , and therefore should be considered undetectable. 


\section{Results.}

Vitamin D-deficiency. - Table 1 shows that in the vitamin D-deficient pigs the mucosal CaBP levels decreased significantly by about 33 p. 100 in the proximal duodenum and by 71 p. 100 in the mid-jejunum ; they remained undetectable in the distal ileum. Table 1 also shows that jejunal CaBP levels represented only 17 p. 100 and 9 p. 100 of the duodenal CaBP levels in control and vitamin D-deficient pigs, respectively.

The plasma $25-\mathrm{OHD}_{3}$ concentration dropped to an undetectable value $(<4 \mu \mathrm{g} / \mathrm{l})$ in the vitamin D-deficient pigs. There was a statistically significant positive correlation between duodenal CaBP levels and plasma $25-\mathrm{OHD}_{3}$ levels :

$$
y=54.7+1.1 x ; \quad r=0.50 ; \quad \text { F. D. }=21 ; \quad P<0.02
$$

where $y$ is the duodenal CaBP content expressed as nmol Ca bound/mg protein (peak B) and $x$ is the plasma $25-\mathrm{OHD}_{3}$ level expressed as $\mu \mathrm{g} / \mathrm{l}$.

The plasma calcium levels of the vitamin D.deficient animals were lower $(p<0.02)$ than in the controls.

Calcium deficiency. - Table 2 shows that when the pigs were placed on a lowcalcium diet for 4 weeks the mucosal CaBP appeared in the distal ileum, rose by about 170 p. 100 in the mid-jejunum, but was not significantly changed in the proximal duodenum. Table 2 also shows that in calcium-deficient pigs the CaBP levels of the jejunal segment approached those of the duodenal segment and that the CaBP content of the ileal segment represented about 20 p. 100 of both other segments. In calciumdeficient pigs the plasma $25-\mathrm{OHD}_{3}$ concentrations dropped to $5 \pm 0.8 \mu \mathrm{g} / \mathrm{l}$ and the plasma calcium concentrations markedly decreased to $76 \pm 5 \mathrm{mg} / \mathrm{l}$.

TABLE 2

Effect of 4-week calcium-deficient diet on duodenal, jejunal and ileal $\mathrm{CaBP}$ contents and plasma $\mathrm{Ca}$ and $25-\mathrm{OHD}_{3}$ levels

\begin{tabular}{|c|c|c|c|c|c|}
\hline \multirow[b]{2}{*}{ Pigs } & \multicolumn{2}{|c|}{ Plasma } & \multicolumn{3}{|c|}{ Intestine } \\
\hline & $\begin{array}{c}\mathrm{Ca} \\
\mathrm{mg} / \mathrm{l}\end{array}$ & $\underset{\mu \mathrm{g} / \mathrm{l}}{25-\mathrm{OHD}_{3}}$ & $\begin{array}{l}\text { Duodenum } \\
\text { CaBP }\end{array}$ & $\begin{array}{l}\text { Jejunum } \\
\text { ol Ca bound } / \mathrm{m}\end{array}$ & $\begin{array}{l}\text { Hleum } \\
\text { protein) }\end{array}$ \\
\hline $\begin{array}{c}\mathrm{NCa} \\
(7)\end{array}$ & $101 \pm 1.4$ & $16 \pm 2.2$ & $75 \pm 14.4\left(^{a}\right)$ & $20 \pm 10.0\left(^{a}\right)$ & $0.0 \pm 0.7\left({ }^{a}\right)$ \\
\hline $\begin{array}{c}\mathrm{OCa} \\
(7)\end{array}$ & $76 \pm 5.1$ & $5 \pm 0.8$ & $54 \pm 6.9$ & $54 \pm 17.5$ & $10 \pm 1.6(a)$ \\
\hline $\mathbf{P}$ & $<0.01$ & $<0.01$ & NS & $<0.01$ & $<0.001$ \\
\hline
\end{tabular}

The values in parentheses represent the number of pigs. The results are the mean $\pm S E M$. Statistical significance was analyzed using Student's t-test : $p$ represents the significance between calciumdeficient pigs and controls. NS : not significant.

( $\left.{ }^{a}\right)$ Significantly different from the other segments $p<0.001$. 


\section{Discussion.}

The present study confirms that in pigs fed a normal calcium, phosphorus and vitamin $D_{3}$-supplemented diet the CaBP levels decrease along the small intestine to become very low or unmeasurable in the ileum. These data agree with previous reports (Arnold et al., 1975 ; Fox et al., 1977).

In addition our results clearly demonstrate that intestinal $\mathrm{CaBP}$ is sensitive to dietary vitamin $D_{3}$. This appears from both the significant decrease in the intestinal CaBP levels in vitamin D-deficient pigs and the positive relationship between duodenal $\mathrm{CaBP}$ and plasma 25-OHD $\mathrm{H}_{3}$ levels. The jejunal segment appears more dependent on dietary vitamin $D_{3}$ than the ducdenal segment. An essential point is that in 7 or 8 -week vitamin D-deficient pigs a large amount of duodenal CaBP is associated with an undetectable plasma 25-OHD 3 concentration. Harrison, Hitchman and Brown (1975) noted no significant decrease in the duodenal CaBP in 3 vitamin D-deficient pigs as compared to 3 control pigs. Our previously reported experiments in the rat indicated that in 6-week vitamin D-deficient rats duodenal CaBP, isolated and measured by the same method, decreased by about 80 p. 100 (22 to $5 \mathrm{nmol}$. Ca bound/mg protein), serum calcium levels fell to $59 \mathrm{mg} / \mathrm{l}$ (Thomasset, Cuisinier-Gleizes and Mathieu, 1977) and serum $25-\mathrm{OHD}_{3}$ concentrations dropped to undetectable values (Thomasset unpublished data). This emphasizes the differences between intestinal CaBP values in control rats and pigs. On the other hand, the vitamin D dependency of intestinal CaBP is more marked in rats than in pigs. The latter difference, however, may be due to the insufficient duration of the vitamin $D$ deficiency in our pig experiments.

The present study also indicates that pigs can adapt to a 4-week calcium deprivation by increasing the concentration of the CaBP in the mid-jejunum and by promoting the CaBP synthesis in the distal ileum without any change in CaBP levels in the duodenal segment. Such data have already been noted in two 2-week calcium-deficient pigs as compared to two control pigs (Arnold ef al., 1975). It is important to note that when pigs were fed a low-calcium dief for 7 weeks, the duodenal CaBP levels rose by about 100 p. 100 (144 vs. 76) (Pointillart, unpublished data). Consequently the response of the duodenal segments seems dependent on the duration of the calcium deficiency and posterior to the adaptation of the mid-jejunum or distal ileum. Thus, pigs as well as rats (Thomasset, Cuisinier-Gleizes and Mathieu, 1977) can adapt to calcium deprivation by increasing intestinal CaBP content.

The rise in CaBP levels in the distal ileum of calcium-deficient pigs is pertinent, since up to now the duodenum rather than the ileum has been considered as a primary target organ for vitamin $D_{3}$. This distal adaptive capacity to increase CaBP synthesis has been reported after massive small bowel resection in pigs (Margolis ef al., 1977). In our study calcium deficiency is associated with a drop in plasma 25-OHD ${ }_{3}$ levels. This decrease may be due to a more rapid conversion of $25-\mathrm{OHD}_{3}$ into $1,25(\mathrm{OH})_{2} \mathrm{D}_{3}$. Indeed it has been reported that renal 25-ODH $\mathrm{ODH}_{3}-1$-hydroxylase activity (Boyle et al., 1972), as well as plasma $1,25(\mathrm{OH})_{2} \mathrm{D}_{3}$ levels (Hughes ef al., 1975), increased in calciumdeficient rats.

The possible association between the increase in CaBP levels and the increase in calcium absorption ability in the different intestinal segments of calcium-deficient pigs has never been thoroughly investigated. Fox ef al. (1977) observed an increase in the 
CaBP level in the distal three-quarters of the small intestine and noted an increase in duodenal calcium absorption without any corresponding increase in the CaBP levels in the same segment.

Thus, intestinal CaBP in pigs is dependent on dietary vitamin $D_{3}$ or dietary calcium. The jejunum appears to rely more on dietary vitamin $D_{3}$ than the duodenum. Adaptation to a low-calcium diet by promoting CaBP synthesis was marked in the jejunum and the ileum. This study suggests that a low-calcium diet promotes intestinal $\mathrm{CaBP}$ synthesis, an expression of the hormonal action of $1,25(\mathrm{OH})_{2} \mathrm{D}_{3}$ in the distal ileum, which is not usually considered as an essential target tissue for vitamin $D$.

Commission CNERNA Digestion-Absorption/Association des Physiologistes, Paris 5-6 octobre 1978.

Acknowledgments. - This study was supported in part by C.R.L. 76.5.201.4 of INSERM and by ATP 2427 of C.N.R.S.

Résumé. Chez le porc carencé en vitamine $D$ la quantité de « CaBP » décroît de $33 \mathrm{p}$. 100 dans le duodénum proximal, de 70 p. 100 dans le jéjunum médian et reste non mesurable dans l'iléon distal. La calcémie chute significativement ef le taux plasmatique de $25-\mathrm{OHD}_{3}$ est indosable. Le porc s'adapte à un régime carencé en calcium en augmentant considérablement son taux de CaBP jéjunale et iléale.

\section{References}

ARNOLD B., KUTTNER M., SWAMINATHAN R., CARE A., HITCHMAN A., HARRISSON J., MURRAY T., 1975. Radioimmunoassay studies of intestinal calcium-binding protein in the pig. $I$. Identification of intestinal calcium-binding protein in blood and response to a low calcium diet. Can. J. Physiol. Pharmacal., 53, 1129-1134.

BELSEY R., DE LUCA H., POTTS J., 1974. A rapid assay for 25-hydroxy vitamin $D_{3}$ without preparative chromatography. J. clin. Endocr., 38, 1046-1051.

BOYLE I. GRAY R., OMDAHL J., DE LUCA H., 1972. Calcium control of the in vivo biosynthesis of 1,25 dihydroxy vitamin $D_{3}$ : Nicolaysen's endogenous factor, 468-476. In TAYLOR S., Endocrinology 1971, Heinemann Medical Books, London.

FOX J., SWAMINATHAN R., MURRAY T., CARE A., 1977. Role of the parathyroid glands in the enhancement of intestinal calcium absorption in response to a low calcium diet. J. Endocr. 74, 345-354.

FREUND T., BRONNER F., 1975. Regulation of intestinal calcium-binding protein by calcium intake in the rat. Am. J. Physiol., 228, 861-869.

HARRISON J., HITCHMAN A., BROWN R., 1975. Intestinal calcium-binding protein in animals fed normal rachitogenic diets : II. Pig studies. Can. J. Physiol. Pharmacol., 53, 144-149.

HUGHES M., BRUMBAUGH P., HAUSSLER M., WERGEDAL J., BAYLINK D., 1975. Regulation of $1 \alpha, 25$-dihydroxy vitamin $D_{3}$ by calcium and phosphate in the rat. Science, 190, 578-580.

MARGOLIS A., RICOUR C., HAROUCHI A., GUYOT M., LAOUARI D., BALSAN S., 1977. Intestinal calcium-binding protein 3 months after massive small bowell resection in the piglets. Am. J. clin. Nutr., 30, 2041-2046.

POINTILLART A., GAREL J. M., GUÉGUEN L., 1978. Calcemia regulation in the vitamin D deficient growing pig. Ann. Biol. anim. Bioch. Biophys., 18, 167-174.

SPENCER R., CHARMAN M., EMTAGE J., LAWSON D., 1976. Production and properties of vitaminD-induced mRNA for chick calcium-binding protein. Europ. J. Biochem., 71, 399-409.

THOMASSET M., CUISINIER-GLEIZES P., MATHIEU H., 1977. Differences in duodenal calciumbinding protein (CaBP) in response to a low-calcium or a low-phosphorus intake. Calcif. Tiss. Res., Suppl. 21, 39-41.

WASSERMAN R. H. TAYLOR A. N., FULLMER C. S., 1974. Vitamin D induced calcium binding protein and the intestinal absorption of calcium. Biochem. Soc. Spec. Publ., 3, 58-74. 